\title{
College approval visits - a perspective on trainee participation
}

\author{
J. Warrington, Y. G. Edmonstone and J. Strachan
}

This toxt discusses whether senior troinees should endecovour to foin a College Approval Panel as ons of the visting tecm, what the advantages would be to the trainees being vitted of hoving a senior troines representolture as a momber of the asceseing group and what the benefils are to senior trainees in ferms of training and broadening thelr own curriculum vilioe.

The Royal College of Psychiatrists has two committees which address the maintenance of standards in postgraduate training. The Joint Committee on Higher Psychiatric Training (JCHPT) addresses senior registrar training while the Central Approval Panel (CAP) reviews senior house officer and registrar training. This paper addresses the second of these systems.

Under the auspices of the CAP, periodic visits are undertaken to all centres providing training to senior house officers and registrars. Each College division is given the responsibility to review schemes in another, often distant division. A divisional convenor is appointed to address the organisation and implementation of visits for a five-year period of office. Visits are conducted in the light of a comprehenstve College document (CAP/01, 1994) supplemented by a separate document outlining expectations of training for general practitioner (GP) trainees in psychiatry (Royal College of General Practitioners and Royal College of Psychiatrists, 1992). Together, these documents cover all aspects of training including administration, facilities, safety, assessment of trainees and the type of training experience offered.

The team for each visit consists of the CAP member who acts as visit convenor, a consultant representing the division and a senior trainee representattve. The senior trainee must be a member of the College. The team also includes an observer from the Royal College of General Practitioners recruited from the area being visited.

Having had prior notification from the College, the local tutor completes a questionnaire detailing the scheme and agrees a timetable for the visit with the convenor. At the end of the visit, the team discuss their findings and present them to the tutor, senior medical staff and trainees at a plenary meeting. The team submits a report for consideration by the CAP and the court of Electors before any recommendations are ratified by the College. The outcome is usually a number of mandatory requirements and recommendations for the accreditation of posts for training.

The process is arranged with the trainees' interests foremost. Although ongoing approval of the scheme and of individual posts is dependent on the range and quality of training provided, no trainee in a post is adversely affected by any decisions involving subsequent nonapproval.

\section{Approval visits from the traince representative's peropective}

The Panel convener consults the Divisional Colleglate Trainee Committee representattve and obtains the names of eligible senior trainees. With the agreement of the appropriate consultant a trainee is invited to participate in the visit. Preparation begins in the week prior to the visit with the deltvery of an alarmingly large bundle of documents from the College detailing the scheme. the posts and visit procedures. The convenor has already been engaged in considerable planning and negotiation with both the College and the schemes to be visited.

The visits are hard work, every minute is accounted for on a whistle stop tour of the schemes and there are reports to write. The convenor is required to deploy organisational skdlls and to keep the team to the task in hand. Each day is carefully structured to allow discussion time with the tutors and regional advisers, the consultant body, academic staff, the trainees (individually and as a group) and senior representatives from management, nursing, soclal work, occupational therapy and psychology.

The trainee representattve is usually able to meet with groups of trainees alone for 
approximately one hour before the arrival of the other panel members. This proves crucial to a full understanding of the scheme from the trainees' perspective. At the end of the day, the panel is often able to meet with senior administrattve staff, in order that any problems highlighted and their implications can be discussed.

The panel tries to visit the main psychiatric units, associated general hospitals including their accident and emergency departments, relevant specialist units and community based services, the electroconvulsive therapy suites, on-call and library facilities. Standards in clinical records are also addressed.

A short session at the end of most days allows the team to meet together to discuss its findings. At the end of the visit some time is scheduled to allow the panel to agree on the content of their report and to identify any mandatory requirements and recommendations to be put forward to the CAP. This report then forms the basis of the feedback sessions, initially to the scheme tutors, then to all involved in the scheme.

\section{Advantages of having a senior trainee representative in the team}

The College stipulates that the senior trainee representative must have the opportunity to spend time alone with the trainees during the approval visit. The advantages of this system are clear. A senior trainee who is either still in post as a registrar or has recently been so is more likely to be viewed by trainees as sympathetic and non threatening. Trainees are more likely to discuss issues such as the faclities avallable while on call in hospital, availability of supervision, out of hours safety, hours of work, inappropriate duties, and conflicts relating to clinical versus academic commitments with a peer. Concerns which may appear trivial to senior colleagues are perhaps more likely to be given greater consideration by another trainee.

In a well organised scheme in which trainees have the opportunity to meet together on a regular basis, the meeting with the trainee representattve may serve only to highlight issues previously raised by the trainee group. In a less cohestve scheme the trainee representative may be able to assist in guiding trainees to look at important areas with respect to their training. including current issues of concern to the Collegiate Training Committee. The trainee representative may also be able to form a view regarding the morale of trainees and the quality of pastoral care.

To be most beneficial, the visiting trainee should have completed registrar training and preferably have started senior registrar training. This places him or her in an ideal position to relate both to the trainees, and to the senior colleagues involved.

\section{Advantages to the senior trainee representative}

Overall, taking part in a visit can be extremely valuable. Potential consultant psychiatrists are likely to be involved in supervising trainees at a later stage and participation sharpens awareness of what constitutes a good and a bad training scheme. The visits also provide some insight into the commitment required in becoming a clinical tutor.

Management training issues are also covered. The level of organisation required by the College, the visiting team and especially by the scheme is daunting. Participation in a visit affords the trainee an excellent opportunity to work with colleagues on a specific task, under pressure of time while taking into account the needs of all parties involved.

Often in the course of training there is little opportunity to address the issue of process. An Approval Panel visit gives an excellent opportunity to look at this in the context of one's own experience and the wider issues of College policies on training. It is possible to gain some understanding of the potential of professional operation.

Inevitably, schemes in other areas differ considerably from the trainee's own experience. Involvement in a visit offers an insight into the complexity of training in a variety of settings. For senior registrars about to embark on consultancy applications the visit gives an excellent opportunity to look at the demands made on senior colleagues and the roles and strategies they adopt to deal with these.

Far from being simply an exercise in critique, a good Panel visit should encompass posittve elements of guidance. Trainees have much to learn from trying to formulate issues in a posittive fashion and in the tactful approaches of senior colleagues in facilitating change.

Of course there are a few drawbacks to being part of the visiting team. First, where geographically separate areas are being assessed there is a considerable time commitment involved, not only in the visit itself, but in getting to and from the areas. The time commitment required both on the visit and in preparation also has to be balanced against meeting clinical obligations when anticipating several days' absence. Expenses for travel and subsistence have to be met initlally by the visiting team members and later reimbursement often takes considerable time. The work schedule is frenetic and a 'heads down approach' is essential. Finally, feeding back any less than favourable 
comments to trainers and trainees may require great tact.

\section{Comment}

Visits by a CAP team often lead to some anxiety for the scheme under the microscope. Trainees in particular may need assistance in formulating their views for presentation to senior colleagues, and a senior trainee is well placed to be able to help. Seniority also allows for clarification of reasonable expectations and in bringing some balance to comments made by trainees. The visits offer invaluable experience in management training and in educational issues. The trainee representative has an essential part to play in a small professional team with an important task to perform.

\section{References}

Central Approval Panel (1994) The Royal College of Psychiatrists Statement on Approval of Trating Schemes for General Professional Trating for the MRCPsych, CAP/01. London: CAP.

ROYAl COUEGE OF GENERAL PRACTmONERs AND ROYAL Colubge of PsYchiatRists (1992) Jotnt Statement on General Practitioner Vocational Tratning in Psychiatry. London: RCP \& RCPsych.

-Jill Warrington, Senior Registrar, Royal Edinburgh Hospital, Morningside Terrace, Edinburgh EH1O 5HF; Yvonne Edmonstone, Consultant Psychiatrist, Craig Dunain Hospital. Inverness; and James Strachan, Consultant Psychiatrist, Royal Edinburgh Hospital

*Correspondence

\section{Prevention of Anxiety and Depression in Vulnerable Groups Joanna Murray}

The scope of this review, commissioned by the Department of Health, is the common mental disorders of anxiety and depression occurring in adults in the community. It considers the possibilities for prevention in primary care. This combination of basic conceptual and research information provides a practical framework of preventive strategies for the primary care team. Social factors in aetiology are examined in detail, and epidemiological data is used to consider vulnerability factors and to identify high risk groups. There is also a thorough review of risk for common mental disorders.

\section{$£ 7.50 \bullet 112 p p . \odot 1995 \bullet$ ISBN 0902241877}

Available from bookshops and from the Publications

Department, Royal College of Psychiatrists, 17 Belgrave Square,

London SW1X 8PG (Tel. 0171-235 2351 extension 146) 